Martin R. Lessard MD, Claude A. Trépanier mD FRCPC, Marie Gourdeau MD FRCPC, Pierre H. Denault MD FRCPC

\title{
A microbiological study of the contamination of the syringes used in anaesthesia practice
}

syringes after the fifth refill. In the second part of their

In many operating theatres, it is common practice to reuse disposable plastic syringes with the same needtes for severat injections to different pasients during the same day. This practice could lead to bacterial contamination of these syringes, making them an infection hazard to parients. We did a microbiologic survey of 100 of the most frequently reused syringes in our operating rooms and a control group of $J 00$ single-use syringes. Only three of the syringes were contaminated in each group. None of the patients exposed to the syringes having a positive culture showed any sign of sepsis. Our data suggest that reusing plastic syringes is not associated with an increase in the incidence of bacterial contamination. However, contamination of the syringes by patients' blood, with the risk of crossinfections, remains a possibility and further studies are needed to evaluate this potential hazard.

In many operating rooms, it is common practice to reuse disposable plastic syringes for several injections to the same patient or to different patients. There are some warnings in the literature stating that this practice could expose patients to infection hazards; the syringes being contaminated after more than one filling. ${ }^{1-3}$ However, in reviewing the literature we found only one related detailed study. ' Blogg et al. demonstrated by an experimental method that mishandling the plunger of a syringe can contaminate it after multiple refills. In that study, all the glass syringes and 50 per cent of the plastic syringes were contaminated after the second refill, and all the plastic

\section{Key words}

EQUIPMENT: syringes, needles; INFECTION: bacteremia; OPERATING ROOMS: contamination.

From the Departments of Anesthesiology and Microbiology, Hôpital de l'Enfant-Jésus, Québec, Québec.

Presented at the meeting of the Association des AnesthésistesRéanimateurs du Québec, April 1987.

Please address correspondence to: Dr. Claude A. Trépanier, Département d'anesthésie, Hôpital de l'Enfant-Jésus, 1401, 18c ne, Québec, G1J 1Z4. investigation, they collected randomly 100 plastic syringes used in operating room and ICU for repeated injections. The culture revealed a contamination rate of eight per cent, half with pathogenic organisms.

In our operating rooms, the same plastic syringes with the same needles are used for repeated injections to different patients in the same operating room during the same day. We were concerned that these syringes could have a high contamination rate, making them a serious infection hazard to our patients. In order to investigate this possibility, we did a microbiologic survey of the syringes used in our current practice.

\section{Methods}

Two hundred syringes were submitted to the microbiology laboratory to detect bacterial growth. They were divided in two groups. Group I, the study group, included seventy-five $5 \mathrm{ml}$ syringes used for repeated injections of succinylcholine or atracurium and twenty-five $10 \mathrm{ml}$ syringes used for repeated injections of fentanyl or sufentanil. These syringes were collected among the most frequently reused in our operating rooms. Each syringe was used during a period of seven hours for several injections to different patients, was handled by the same anaesthetist, who wore no gloves. The syringes were stored on the anaesthesia cart.

Group two, the control group, included seventy-seven 5 $\mathrm{ml}$ syringes used for injections of succinylcholine or atracurium and twenty-three $10 \mathrm{ml}$ syringes used for injections of fentanyl. These syringes were filled only once and used for one patient only.

For both groups the injections were made into the injection sites of the intravenous lines, never directly into the patient's vein. The IV set used was the Travenol JC0127, which includes a check valve. Immediately after use, the empty syringes with their needles were sent to the laboratory. Five or ten $\mathrm{ml}$ of trypticase soy broth (TSB) were aseptically aspirated into the syringes with the needle. Then $0.2 \mathrm{ml}$ were plated on blood agar (BA). The incubation was under aerobic conditions at $35^{\circ} \mathrm{C}$, for 72 hours for BA and 14 days for TSB. Any bacterial growth 
TABLE Conıaminated syringcs

\begin{tabular}{lll}
\hline Syringes & No of refilis & Organism \\
\hline Study group & & \\
$5 \mathrm{ml}$ & 6 & Pseudomonas vesicularis \\
$5 \mathrm{ml}$ & 3 & Staphylococcus epidermidis \\
$10 \mathrm{ml}$ & 3 & $\begin{array}{l}\text { Enterobacter cloacac } \\
\text { Staphylococcus epidermidis }\end{array}$ \\
& & \\
Control group & & Staphylococcus epidermidis \\
$5 \mathrm{ml}$ & 1 & Staphylococcus epidemidis \\
$5 \mathrm{ml}$ & 1 & Coryncbacterium sp. \\
$5 \mathrm{ml}$ & 1 &
\end{tabular}

was noted and the organism(s) were identified according to the regular standards used in bacteriology laboratories. In order to detect any sign of bacteraemia, we reviewed the charts of all the patients who had heen exposed to one of the syringes that showed a positive culture. We looked for one of the following signs of bacteraemia: body temperature over $38.5^{\circ} \mathrm{C}$, any observation of an infectious episode, any positive bacterial culture or any use of antibiotics, except for prophylaxis.

From a typical working day in our operating room, we evaluated how many syringes and needles are used in our current practice and how many would be required if the syringes were used only once. Then we estimated the costs for one year.

\section{Results}

In the study group, seventy-five $5 \mathrm{ml}$ syringes with a mean tefilling rate of 3.59 and twenty-five $10 \mathrm{ml}$ syringes with a mean refilling rate of 3.56 were cultured. The global mean refilling rate was 3.58 . The bacterial culture revealed three contaminated syringes in both the control and study group. The bacteriological data are summarized in the Table. The global contamination rate in each group was three per cent. All the other cultures were negative after 14 days. No patient exposed to the contaminated syringes had any clinical evidence of bacteraemia or sepsis upon reviewing charts with the methodology stated above.

We currently use about 25,000 disposable plastic syringes for approximately 10,000 cases per year. Replacing every empty syringe with a new one would mean using about 56,000 syringes. This would imply a 110 per cent increase in the expenses related to syringes and necdles which in our practice means an increase of $\$ 5,000.00 /$ year.

\section{Discussion}

In Group I, we purposely examined the most frequently reused syringes in our practice. As a result, the average filling rate of the syringes (3.58) overestimates the average filling rate in our operating room (2.1 in a typical day survey). Even then, we found exactly the same contamination rate in both the study and the control groups. Blogg et al. found that contamination increases with the number of refilling; however, in their study the gloved right hand of the investigator had been previously dipped into a culture of Serratia marcescens. ${ }^{1}$ This is obviously not equivalent to the usual clinical setting and our data suggest that refilling is a minor factor in bacterial contamination of plastic syringes. More likely sources of contamination are the puncture of the injection site, recapping of the needle and mishandling by the anaesthetist.

Our incidence of contamination is less than half that which Blogg et al. reported in the second part of their study.' Two possible reasons for this difference might be considered: first, a difference in the physical characteristics of our syringes could make them less susceptible to contamination than those used by Blogg (e.g., better seal of the plunger); secondly, differences in working habits between the two groups (e.g., frequency of handwashing, storage of the syringes during the procedure, etc.). It is doubtful that this difference can be explained by our bacteriological technique. Blogg et al. do not describe theirs, but they report incubation for only 48 hours. We incubated the blood agar for 72 hours and TSB for fourteen days. Enriched broth like TSB provides fertilization of organisms present in very small number and facilitates isolation of even fastidious organisms. ${ }^{4}$

The cost related to the syringes and needles is another important factor that must be consicered. A review of these costs in our operating rooms over one year showed that using a sterile syringe for each reinjection would imply a 110 per cent cost increase which in our practice (approximately 10,000 cases/year) is equivalent to $\$ 5,000.00 / y e a r$. In the actual trend of cost-containment effort, this is not a negligible figure and must be taken into account. Furthermore, this number would be increased several fold if the cost of the discarded drugs were included in the calculation

Our data indicate, that the incidence of bacterial contamination does not justify changing syringes for every case. However, another possible hazard is the contamination of the needle or syringe by the patient's blood refluxing in the IV tubing with the risk of cross-infections between patients. One study indicates that it is a possibility, but the authors do not mention if their IV tubing had a check valve like our material.s Further stuclies of the ability of check valves to prevent blood reflux are needed before we can affirm the total safety of reusing syringes.

\section{Acknowledgement}

The authors thank Drs Claude A. Tremblay and Michel 
Rouillard for reviewing the manuscript, and Mrs Suzanne B. Koenig for secretarial assistance.

\section{References}

1 Blogg CE. Ramsay MA, Jarvis JD. Infection hazard from syringes. Br J Anaesth 1974; 46: 260-2.

2 Heseltine $P$. Ancsthcsiologists should not give IV medications with common syringe. Hospital Infection Control 1986; 13: 84-85

3 Scurr CF, Edgar WM. A possible danger of all-glass syringes. Lancer 1962; 1: 1303-4.

4 Isenberg HD, Schoenknecht FD, von Graevenitz A. Collection and processing of Bacteriological Specimens. American Socjety for Microbiology. Wașhington. 1979: 4-5.

5 Hein HAT, Reinhant RD, Wansbourgh SR, Jantzen $J$-PAH, Giesecke $A H$. Recapping needles in ancsthesia. Anesthesiology 1987; 67: A161.
Résumé

Dans plusieurs salles d'opération, les mèmes seringues de plastique jenables avec l'aiguille sont réutilisées pour plusieurs injections à différents patients durant une même journée. Cente pratique pourrait entraîner une contamination bactérienna de ces seringues et exposer des patients à des risques d'infection. Nous avons effectué une étude microbiologique de cent seringues parmi les plus fréquemment réutilisées dans notre milieu ainsi qu'in groupe contróle de cent seringues n'ayant été utilisées qu' une seule fois. Seulement trois des seringues se sont révélées conlaninées dans chacun des groupes. Aucun des patients exposés à ces seringues n'a présenté de signes de bacrériémis. Nos résultats suggèrent que ta réutilisation des seringes de plastique n'est pas associée à une plus grande fréquence de contamination bactérienne. Cependant la contamination des seringues par du sang des patients avec le risque associé d' infection croisée demeure une passibilité er d'autres études sont nécessaires afin d'évaluer ce risque. 